http://dx.doi.org/10.12775/szhf.2015.008

\author{
JERZY KOJKOE
}

Akademia Marynarki Wojennej, Gdynia

\title{
Immanuel Kant w Polsce - wybrane problemy recepcji przełomu XIX i XX wieku
}

Hasło powrotu do filozofii I. Kanta rzucone przez Otto Liebmanna w książce Kant und die Epigonen z 1865 roku było jednym z wielu przejawów popularności, jaką neokantyzm zdobył sobie w niemieckich kołach akademickich w latach 1860-1900. Pogląd ten trafił też do innych krajów - m.in. dzięki rozkwitowi społeczno-politycznemu i ekonomicznemu Prus, reformom oświatowym i rozwojowi kultury, a także zjednoczeniu państw niemieckich oraz powstaniu silnej gospodarczo Rzeszy Niemieckiej, prowadzącej ekspansjonistyczną politykę wobec sąsiadów ${ }^{1}$.

Kantyzm wydawał się wówczas nie tylko szczytem w rozwoju teorii poznania, ale również ostatnim stopniem prowadzącym do kresu rozwoju filozofii. Nie chodziło bynajmniej o zaprzeczenie tendencji rozwojowej poznania ludzkiego, lecz o stwierdzenie jego ostatecznego ukierunkowania. Kantyści byli przekonani, że poznanie rozwija się i nadal będzie się rozwijać w kierunku określonym przez I. Kanta, dlatego stanowisko swoje nazwali kryty-

${ }^{1}$ Zob. W. Dobrzycki, Historia stosunków międzynarodowych w czasach nowożytnych (1815-1990/91), [w:] Stosunki międzynarodowe - geneza, struktura, dynamika, red. E. Haliżak, R. Kuźniar, Warszawa 2006, s. 64-67; A. Galos, Cz. Czapliński, Historia Niemiec 1789-1871, Warszawa 1980, s. 653; M. Kukiel, Dzieje polityczne Europy od rewolucji francuskiej, Londyn 1992, s. 592; E. Tarle, Dzieje Europy (1871-1919), Warszawa 1961, s. 300. 
cyzmem, który miał być kantyzmem zmodernizowanym, zwanym częściej neokantyzmem².

W ujęciu Hermanna von Helmholtza, Kuno Fischera, Otto Liebmanna, Friedricha Alberta Lange, Hermana Cohena czy Wilhelma Windelbanda bycie kantystą oznaczało traktowanie filozofii przede wszystkim jako krytyki poznania, co prowadziło do rezygnacji z teorii bytu. W doświadczeniu dostrzegano złożony twór umysłu, który jest uwarunkowany jego apriorycznymi formami. Poza granice tak określonego doświadczenia poznanie ludzkie, jeśli nie chce popaść w „starą metafizykę", nie może wyjść. Bycie kantystą znaczyło zatem bycie realistą, uznawanie rzeczy, które przejawiają się umysłowi poznającemu jako istniejące realnie, będące pewną nieuwarunkowaną nim rzeczywistością dualistyczną, dopuszczającą możliwość zaistnienia doświadczenia wewnętrznego i zewnętrznego. Kantysta był więc także dualistą i formalistą, co oznaczało uznawanie wiedzy skonstruowanej przez umysł za pewną, powszechną i konieczną formę poznania podmiotowo-przedmiotowego, ograniczoną możliwością doświadczenia.

W kantyzmie dostrzegano także motyw minimalistyczny i maksymalistyczny. Uważano, że I. Kant wykazał, iż teoretycznymi dochodzeniami nie można dosięgnąć „rzeczy w sobie”, ponieważ poznanie ich jest możliwe wtedy, gdy odwołuje się do postulatów życia. Z jednej więc strony, jak minimaliści, krytykował całą dotychczasową metafizykę, ale z drugiej zdawał się zapowiadać nową metafizykę, niczym maksymaliści. Taką interpretację kantyzmu dali przede wszystkim F. A. Lange i H. Helmholtz, którzy pod-

2 Por. W. Tatarkiewicz, Historia filozofii, t. 3, Warszawa 1990, s. 93. Pisał on o neokantystach, że: „usiłowali utrzymać samą tylko nową ideę Kanta, eliminując to, co w jego pismach było pozostałością przedkantowskiej filozofii. Usiłowali wydobyć samo złoto, odrzucając rudę. Chcieli dokonać rektyfikacji kantowskiej spuścizny. Mówiąc bez przenośni, chcieli z amalgamatu elementów przedkantowskich i swoiście kantowskich, jakimi są trzy Krytyki, wydzielić tylko elementy swoiście kantowskie". W. Tatarkiewicz, $W$ dwieście pięćdziesiąta rocznicę urodzin Kanta, [w:] Dziedzictwo Kanta, Warszawa 1976, s. 11. Wydaje się, że W. Tatarkiewicz tylko częściowo miał rację. W Polsce bowiem dominowała i dominuje tendencja $\mathrm{z}$ jednej strony do eksponowania granic i praw poznania racjonalnego. Przeciwstawiania I. Kanta metafizyce, podkreślania, że rozum ludzki musi się trzymać granic doświadczenia. Z drugiej strony da się dostrzec irracjonalizację tego doświadczenia. Obie tendencje wynikają jednak z tradycyjnej, idealistycznej interpretacji kantyzmu. Zob. także Filozofia Kanta i jej recepcja, red. D. Bęben, A. J. Noras, Katowice 2011; Filozofia Kanta i jej recepcja, red. nauk. R. Kozłowski, Poznań 2000; L. Kołakowski, Immanuel Kant, [w:] O co nas pytaja wielcy filozofowie, Kraków 2006; T. Kupś, Filozofia religii Immanuela Kanta, Toruń 2008; M. Żelazny, Idea wolności w filozofii Kanta, Toruń 2001. 
kreślali fenomenalizm i subiektywizm Kanta. W refleksji tej umysł stawał się wszystko po swojemu konstruującym narzędziem poznania. Myśl była równie subiektywna jak wrażenia, co prowadziło do subiektywności ludzkiego poznania. Wydaje się, że można tę interpretację kantyzmu określić mianem psychologicznej ${ }^{3}$.

Tej ostatniej wizji, pod koniec XIX w., przeciwstawiał się m.in. Stanisław Garfein-Garski, negujący konieczność całkowitego zespolenia osiągnięć nauk przyrodniczych z filozofią I. Kanta. Określał - tak postrzegany kantyzm mianem „pozytywizmu idealnego” lub „nowo-kantyzmu”. Uważał za „pozbawioną przyszłości, pochłanianą przez mroki historii wersję filozofii Kanta”.

Taki los, zdaniem Garfeina-Garskiego, miał spotkać także najwybitniejszego nowokantystę w ówczesnych Niemczech, Fritza Schultze 4 , który, obrawszy sobie za punkt wyjścia psychologię traktowaną jako gałąź nauk przyrodniczych niezależną od filozofii, doszedł do metafizyki woli w formie duszo-materii, czyli psychady. Myśliciel, odróżniając duszę od umysłu, uznał konieczność najogólniejszego określenia procesów psychicznych, tj. korelacji nieświadomych czynności psychicznych ze świadomymi, w szczególności

${ }^{3}$ Po roku 1880 pisali o Kancie m.in.: S. Harassek, W. M. Kozłowski, S. Smolikowski, M. Straszewski, W. Rubczyński, A. Mahrburg, M. Massonius, M. Wartenberg, A. Żółtowski. Dla wielu autorów podstawą poglądów epistemologicznych była psychologia. Przykładem może być A. Raciborski, który pisał, że „cała teoria poznania polega w znacznej części na krytycznym rozbiorze doniosłości i znaczenia działań psychicznych". A. Raciborski, Ogólny zarys systemu filozofii, t. 1, Lwów 1892, s. XI. Por. Osiągnięcia polskiej psychologii w okresie międzywojennym, red. K. Czarnecki, Katowice 1981, s. 150. Szerzej na temat recepcji Kanta zob. K. Bochenek, L. Gawor. M. Michalik-Jeżowska, R. Wójtowicz, Zarys historii filozofii polskiej, Rzeszów 2013, s. 188; K. Bochenek, L. Gawor, A. Jedynak, J. Kojkoł, Filozofia polska okresu międzywojennego. Zarys problematyki, Gdynia 2013, na różnych stronach; S. Borzym, Filozofia polska 1900-1950, Wrocław-Warszawa-Kraków 1991, s. 12, 21-29; L. Gawor, Myśliciele mało znani. Filozofia polska końca XIX wieku i pierwszej dekady XX wieku, Rzeszów 2001, s. 22-23; J. Skoczyński, J. Woleński, Historia filozofii polskiej, Kraków 2010, s. 329-334; Zarys dziejów filozofii polskiej 1815-1918, red. A. Walicki, Warszawa 1983, s. 168-183.

${ }^{4}$ Doktor Fritz Schultze (1846-1908) był w tym czasie profesorem filozofii w Dreźnie. W książce pt. Spirytyzm, czyli o obcowaniu $z$ duchami, Warszawa 1884, s. 64 pisał: „Kant dokonał wielkiej zmiany w filozofii: $\mathrm{z}$ dogmatycznej uczynił ją krytyczną. Filozofia dogmatyczna starała się wyjaśnić rzeczy leżące poza obrębem naszego doświadczenia i możliwością naszego poznania, mówił o rzeczach boskich i pozagrobowych. Kanta filozofia krytyczna ograniczyła badanie na jedynie nam dostępnej dziedzinie doświadczenia. Kant dał odprawę dogmatycznej filozofii”. F. Schultze był autorem m.in. Stammbaum der Philosophie, Vergleichende Seelenkunde (1892), Psychologie der Naturvölker. Zob. Gutenberg-Konversations Lexikon, 1930/1931, t. 1, s. 763. Zastanawiające jest, dlaczego ten autor był prawie nieznany polskiej refleksji neokantowskiej. 
myślenia i woli. Jego zdaniem rozwiązanie problemu duszy będzie jednocześnie rozwiązaniem zagadnień związanych $\mathrm{z}$ funkcjonowaniem wszechświata i jego stworzeniem ${ }^{5}$.

Psychologiczna tradycja mogła uzupełnić kantyzm o ontologię, gdyż refleksja nad poznaniem wydaje się jednocześnie refleksją nad sposobem bycia i podstawowymi formami przedmiotowości, czyli bytu, który „jawi” się temu poznaniu. Krytyka stawia sobie zatem pytanie o warunki naszego poznania, o ile są one jednocześnie warunkami funkcjonowania przedmiotów. Pytania krytyki w ujęciu psychologicznym mogły dotyczyć zarówno Umysłu, jak i Bytu, ich jedności oraz wspólnej podstawy gwarantującej zachowanie wzajemnych relacji w ramach struktury złożonej, w łonie której są dopiero odróżnialne i porównywalne. I. Kant sygnalizował możliwość zaistnienia Ontologii Wiedzy, kantyści mogli ją stworzyć, lecz ani F. Schultze, ani jego współcześni tego nie zrobilí'. S. Garfein-Garski dostrzegł, że ontologia może być punktem wyjścia kantyzmu, punktem wyjścia krytyki, ponieważ prawomocności nauki trzeba szukać w całościowej strukturze świata empiryczno-racjonalistycznego. Ontologia zatem jest także punktem dojścia krytyki. Dlatego dostrzegając ważność psychologii i wpływu na nią nauk przyrodniczych, krytykował psychologiczną interpretację twórczości I. Kanta.

Wydaje się, że intencja I. Kanta była jeszcze bardziej złożona. Nie zadowalała go ani psychologiczno-filozoficzna, ani epistemologiczna krytyka. Jego zamysłem było stworzenie złożonej struktury, której częścią składową byłaby krytyczna teoria poznania. W apriorycznych formach widział nie tylko właściwości umysłu ludzkiego, ale również warunki funkcjonowania przedmiotów oraz ich poznania przez podmiot w określonych strukturach ontologicznych. Spełnienie tych warunków umożliwiałoby zaistnienie odmienności poznawczo-ontologicznej. I. Kant pisał:

dialektyczny pozór (występujący) w psychologii rozumowej polega na pomieszaniu pewnej idei rozumu (czystej inteligencji) z nieokreślonym pod żadnym względem pojęciem istoty myślącej w ogóle. Dla uzyskania możliwego doświadczenia, lecz abstrahując jeszcze od wszelkiego rzeczywistego doświadczenia, myśląc siebie samego i wznosząc stąd, że mógłby mieć świadomość

\footnotetext{
${ }^{5}$ Por. S. Garfein-Garski, Psychada, „Ateneum”, 1892, t. 4, s. 490. W pracy tej zostają omówione zasadnicze myśli zawarte w książce Fritza Schultze: Vergleichende Seelenkunde, Leipzig 1892.

${ }^{6}$ Możliwość takiej interpretacji przedstawił także M. J. Siemek. Por. tenże, Transcendentalizm jako stanowisko epistemologiczne, [w:] Dziedzictwo..., s. 31.
} 
mego istnienia także poza doświadczeniem i jego warunkami empirycznymi. W następstwie tego możliwe abstrahowanie od mego empirycznie określonego istnienia mieszam z rzekomą świadomością możliwości odrębnego istnienia mego myślącego Ja i jestem przeświadczony, że to co substancjonalne we mnie poznaję jako podmiot transcendentalny, mając (naprawdę) na myśli jedynie jedność świadomości, która jako sama tylko forma poznania leży u podstaw wszelkiego określenia ${ }^{7}$.

W tym poglądzie I. Kanta można wyróżnić: subiektywną treść świadomości, czyli faktyczne postrzeżenia i wyobrażenia w świadomości indywidualnej, obiektywny świat zjawisk oraz rzeczywistość, która sama w sobie istnieje bez względu na jakikolwiek podmiot. Subiektywna treść świadomości istnieje tylko dla określonego podmiotu. Świat zjawisk jest podobny dla wszystkich podmiotów, w nim główną rolę odgrywają prawa przyrody, ogólne związki między pierwiastkami w przestrzeni i czasie. Rzeczywistość myślna natomiast ująć się daje tylko myślą, jako pewne pojęcie niedostępne zmysłom postrzegania, choć wynikające także z rzeczywistego, doświadczalnego świata. Pomijając to potrójne rozróżnienie, popadamy w irracjonalne uwarunkowania zracjonalizowanej rzeczywistości społecznej. Wydaje się, że tą drogą poszedł modernizm, a później postmodernizm.

W poglądach S. Garfeina-Garskiego można dostrzec chęć poruszania się $\mathrm{w}$ świecie rzeczy, które są dostępne postrzeżeniom zmysłowym teraz lub w przyszłości, ale które wiążą się jednocześnie z „podkładem substancjonalnym". Istnieją ponadto zjawiska psychiczne zmysłowo niepostrzegalne, które rozważane nie dają żadnego powodu do przyjmowania „podkładu substancjonalnego". Połączenie ich w ustroju ludzkim polega na wzajemnym oddziaływaniu. Pogląd ten prowadził do krytyki psychologizmu oraz tradycyjnej interpretacji kantyzmu przypisującej „zjawisku” właściwości irracjonalne.

Przekonanie to zostało uwypuklone w artykule S. Garfeina-Garskiego pt. Krytycyzm. Na podstawie jego analizy dochodzi się do wniosku o słuszności stwierdzenia Stanisława Borzyma, że S. Garfein-Garski cenił najbardziej krytycyzm I. Kanta. Zwalczał uproszczoną subiektywistyczno-psychologiczną wykładnię kantyzmu, ponieważ zacierała istotę filozofii krytycznej, zacierała ukazanie możliwości koniecznego i powszechnego poznania w granicach doświadczenia8.

\footnotetext{
${ }^{7}$ I. Kant, Krytyka czystego rozumu, t. 2, Warszawa 1957, s. 137.

${ }^{8}$ Por. S. Borzym, Poszukiwania nowej epistemologii, [w:] Zarys dziejów filozofii.., s. 233.
} 
Uznawał on krytycyzm za najgłębszy filozoficznie kierunek teoriopoznawczy, który istotę dostrzega tam, "gdzie dla racjonalizmu i empiryzmu wszelkie poznanie się kończy". Jego wskazówkami nie są ani z góry założone cele poznawcze, ani pragmatyczne względy użyteczności, lecz jedynie i wyłącznie poszukiwanie prawdy. Krytycyzm uznaje współdziałanie zmysłowości i myślenia za źródło obiektywnego poznania, rozróżnia formę i materię doświadczenia oraz przyjmuje pewne aprioryczne czynniki doświadczenia i poznania za dane parazmysłowe. Pomimo takiego - zdawać by się mogło ścisłego - zdefiniowania pojęcia krytycyzmu, S. Garfein-Garski rozumiał, że jest on bardzo szerokim nurtem myśli ludzkiej'.

W polskiej myśli filozoficznej przełomu XIX i XX wieku podkreślano często, że postacie przejawiania się krytycyzmu były bardziej bogate teoretycznie niż to, co zostało usankcjonowane w filozofii transcendentalnej I. Kanta. Podobnie rozumował W. Jerusalem, który pisał: „krytyczna w pewnym znaczeniu jest filozofia już w swoich początkach. Przez to, że postanowiła osiągnąć pogląd na świat siłą własnego myślenia, niezależnie od tradycji, w istocie jej w pewnym stopniu tkwi już krytycyzm" ${ }^{10}$. Komentując tę myśl, S. Symotiuk pisał:

${ }^{9}$ Por. S. Garfein-Garski, Krytycyzm, [w:] W poszukiwaniu prawdy, Kraków 1911, s. 98. Jest to jeden z sześciu wykładów wygłoszonych w auli Uniwersytetu Jagiellońskiego w 1909 roku przez sześciu prelegentów: Tadeusza Grabowskiego, Franciszka Gabryla, Wojciecha Gieleckiego, Ignacego Wasserberga, Stanisława Garfeina-Garskiego i Maurycego Straszewskiego, wydanych przez tego ostatniego w 1911 roku.

${ }^{10}$ W. Jerusalem, Wstęp do filozofii, Warszawa 1926, s. 55. Takie szerokie rozumienie krytycyzmu jest tylko częściowo zgodne z polską tradycją filozoficzną przełomu XIX i XX wieku. Już bowiem w latach osiemdziesiątych wieku poprzedzającego nasze stulecie daje się zauważyć kształtowanie nowej formuły filozoficznej programów antymetafizycznych, zwanej przez jej rzeczników „nowokrytycyzmem”. Formuła ta jednakże nie odpowiadała pojęciu „neokantyzm” rozumianemu w historii filozofii europejskiej jako określenie dla różnorodnych odmian stanowisk neokantowskich. Polski nowokrytycyzm był związany przede wszystkim z naturalistyczno-ewolucjonistyczną wykładnią kantyzmu, która mogła być odczytywana jako stanowisko zbieżne z pewnymi tezami pozytywistycznymi. Swój neokantowski akces - zaznacza A. Hochfeldowa - polscy nowokrytycyści traktowali jako wyraz pozytywizmu w jego formie nowoczesnej, tzn. wzbogaconej krytyczną teorią poznania I. Kanta, przeformułowaną w duchu ewolucjonizmu i współczesnych osiągnięć psychologii. Znamienną cechą tego kierunku było kontynuowanie tradycji zarówno kantyzmu, jak i wszystkich współczesnych nurtów filozofii pozytywistycznej, od empiriokrytycyzmu po fizykalizm, oraz korzystanie z metodologicznych treści właściwych nowoczesnemu przyrodoznawstwu. Rezonans tak szeroko pojmowanego prądu teoretycznego był dość duży, często sprowadzał się on jednak do akceptowania pojedynczych tez tego stanowiska. „Nowokrytycyzmowi okazywali życzliwość przyrodnicy, 
gdy wedle słów W. Jerusalema, każdy akt filozofowania jest $\mathrm{z}$ istoty krytyczny, to u Habermasa filozofia jest tożsama z krytyką dopiero w efekcie ewolucji i samooczyszczenia. Tak też staje się u Kanta, gdy pozbywa się ontologii. Kant zainicjował poczucie kryzysu i zmierzchu filozofii, a nawet unikał słowa filozofia. Krytycyzm wyrasta z filozofii, lecz nie jako zjawisko służebne, lecz nadrzędne ${ }^{11}$.

Takiego typu stanowisko krytycznie oceniał już ponad 80 lat wcześniej H. Struve, dla którego przerost krytycyzmu może powodować „lubowanie się" w wyszukiwaniu stron ujemnych, wad i braków. Krytycy mogą być ludźmi, którzy wszystkiemu zaprzeczają, szukają dla wszystkiego antytezy, są chwiejni i nieokreśleni, „bezwzględni w negacji krytycznej”. Ich krytyka bez chwili wytchnienia poszukuje sprzeczności, wątpi dla wątpienia. Jej wyznawcy mogą być malkontentami zaciekle podkopującymi wszystkie poglądy, mizantropami dopatrującymi się we wszystkim hipokryzji lub niskich motywów, obłudy i oszustwa, „ze śmiechem szyderczym na ustach lub z samobójczą zuchwałością w sercu brną po takich błotach krytycznych". H. Struve uważał, że dlatego właśnie nazwa filozofii krytycznej stała się dzisiaj powszechna i nie może być synonimem kantyzmu. Każdy bowiem współczesny myśliciel, bez względu na orientację teoretyczną, do której można zaliczyć jego poglądy, uznaje krytykę czynności poznawczych za trwały składnik filozofii w ogóle. Domaga się tym samym, żeby uznano jego krytycyzm. Tym właśnie różni się filozofia współczesna - podkreśla H. Struve - od filozofii poprzednich pokantowskich okresów, tzn. metafizycznego idealizmu czy materializmu. Tym właśnie przejawia się wpływ I. Kanta na myśl współczesną. „Jego krytycyzm poznawczy stał się udziałem wszystkich poważniejszych myślicieli ostatniej doby"12. H. Struve zwrócił uwagę na pewne ograniczenia hasła krytycyzmu.

jak np. Antoni Złotnicki. Wyraźnie skłaniali się ku niemu niektórzy pisarze parający się humanistyką, jak Ignacy Matuszewski i Piotr Chmielewski [...]. Jako zwolennicy nowokrytycznego programu filozofii naukowej deklarowali się Ludwik Krzywicki i Stanisław Krusiński”. Ze względu na nieokreśloność, fragmentaryczność i powierzchowność tych filozoficznych deklaracji, nowokrytycyzm można traktować jako pewną myślową orientację odbiegającą znacznie od teoretycznej jednolitości i jednoznaczności lansowanych poglądów filozoficznych. Filozofia nowokrytyczna miała być zatem ewolucjonistyczno-pozytywistyczną teorią bytu, uzupełnioną kantowską teorią poznania. Por. A. Hochfeldowa, Orientacja nowokrytyczna, [w:] Filozofia i myśl społeczna w latach 1865-1895, red. A. Hochfeldowa i B. Skarga, Warszawa 1980, s. 70.

${ }^{11}$ S. Symotiuk, Pojmowanie krytycyzmu i model krytyki w polskich pracach filozoficznych, Lublin 1987, s. 16.

${ }^{12}$ Por. H. Struve, Wstęp krytyczny do filozofii, czyli rozbiór zasadniczych pojęć o filozofii, Warszawa 1903, s. 654 oraz tenże, Immanuel Kant oraz dziejowa doniosłość jego krytycyzmu, War- 
Miał to być krytycyzm ostrożny, oparty na pewnych danych zmysłowych, kształtujący się z uwzględnieniem naukowych zdobyczy rozumu ludzkiego.

Kolejny myśliciel, M. Massonius, uważał, że filozofią nowokrytyczną można określić te nurty, które swoją pełnię teoretyczną ukształtowały w latach osiemdziesiątych dziewiętnastego wieku, a ponadto za podstawowy paradygmat metodologiczny uznają wyniki teorii poznania I. Kanta. Filozofia zatem stawała się krytyką władzy poznania opartą na ogólnych osiągnięciach wszystkich lub niektórych nauk szczegółowych. Jej podstawą miała być filozoficzna reforma I. Kanta, stanowiąca „w swej czystej postaci uwieńczenie rozwoju empiryzmu"13.

Omawiani myśliciele uważali, że polskie nieporozumienia wokół I. Kanta biorą się stąd, że jego prace, będące przejawem wielkiej głębi myślenia teoretycznego, torujące nowe drogi filozofii, stwarzające warunki dla duchowego przewrotu, nie „bywają prawie wcale czytane w oryginale”. Nieszczęśliwy przypadek tworzy obraz, który jest zupełnym skrzywieniem i wykoślawieniem myśli I. Kanta. Taki obraz uzyskuje samoistną autonomię, funkcjonuje jako prawowierna myśl autora i on właśnie służy za przedmiot krytyki i polemik. Często przypisuje się I. Kantowi słowa, których nigdy nie mówił i poglądy, których nigdy nie głosił, a najpewniej by przeciw nim protestował. Wystarczy jednak odwołać się do oryginału, by wszystkie zarzuty, cała fałszywa polemika prysła jak bańka mydlana ${ }^{14}$. Słowa te są również dzisiaj aktualne.

Polskie reminiscencje wokół myśli I. Kanta dotyczyły także roli doświadczenia empirycznego w poznaniu. Dominujące było przekonanie, że I. Kant uznał, iż rozum bez żadnego doświadczenia, bez żadnego materiału, bez żadnego dostarczanego przedmiotu może dokonywać aktu poznania. Takie ujęcie krytykował S. Garfein-Garski, pisząc:

szawa 1904, s. 9. Zob. „Przegląd Filozoficzny”, nr 1 z 1897/98 oraz nr 4 z 1901 r. Tam dyskusja nt. filozofii krytycznej.

${ }^{13}$ Por. Przedmowa M. Massoniusa do: Filozofia nowokrytyczna, Warszawa 1905, s. I.

${ }^{14}$ A. Hochfeldowa pisała: „Przedstawicielem neokantyzmu szczególnie w Polsce popularnym stał się z początkiem lat osiemdziesiątych F. A. Lange: Historia filozofii materialistycznej wyszła po polsku w 1881 r. z inicjatywy A. Świętochowskiego i częściowo we własnym jego przekładzie. Wpływowym autorem z kręgu spozytywizowanego neokantyzmu był A. Riehl, podczas gdy kierunek zainicjowany przez Cohena nie znalazł w tym czasie rezonansu. Co się tyczy dzieł samego Kanta, polskie ich wydania ukazać się miały dopiero z początkiem następnego stulecia: Prolegomena w przekładzie R. Piątkowskiego w 1901 r., Krytyka czystego rozumu w przekładzie P. Chmielewskiego w 1904 r., Uzasadnienie metafizyki moralności w przekładzie M. Wartenberga w 1906 r.". Por. tejże: Orientacja..., s. 69. Dla ścisłości należy stwierdzić, że twórczość Cohena była w Polsce znana, o czym świadczy dorobek W. M. Kozłowskiego. 
Kant stwierdza wyraźnie, iż nie ulega żadnej wątpliwości, że wszelkie nasze poznanie rozpoczyna się wraz z doświadczeniem. Mówi on np. „co do czasu żadne poznanie nie poprzedza doświadczenia” albo: „wszelkie poznanie z czystego rozsądku tylko albo czystego rozumu nie jest niczym więcej niż pozorem i tylko w doświadczeniu jest prawda". Czyli Kantowi nie śniło się nawet o tym, co mu zarzucają ${ }^{15}$.

Mniejszą rolę doświadczeniu w filozofii I. Kanta przyznawał H. Struve. Według niego I. Kant twierdzi, że poznanie zostaje pobudzone na skutek doświadczenia, że od niego rozpoczynają się procesy poznawcze, jednakże poznanie nie wypływa całkowicie z doświadczenia. Doświadczenie jest czynnością umysłu, który podlega właściwym sobie formom i prawom, według nich uświadamia sobie wrażenia wywoływane przez świat przedmiotowy. I. Kant wnioskuje, że na poznanie składają się dwie różne grupy czynników: pierwsze właściwe samemu rozumowi, czyli czynniki „czyste”, zwane też a priori oraz druga grupa czynników, zwanych empirycznymi - a posteriori. Badanie tych czynników przy uwzględnieniu ich wzajemnego stosunku nazywa I. Kant transcendentalnym, gdyż przekracza bezpośrednio dane doświadczenia, mając na celu wyjaśnienie jego ostatecznych podstaw. To badanie stanowi dla I. Kanta przedmiot osobnej nauki, nazwanej przez niego krytyką i mającą charakter propedeutyki, czyli wstępu do metafizyki traktowanej jako właściwa filozofia. Całościowy system filozoficzny powinien „oprzeć się całkowicie na wynikach krytyki”"16.

Kantowski aprioryzm był dla H. Struvego tylko skrajną postacią subiektywistyczno-sceptycznej wizji filozofii, negującą istnienie obiektywnego świata. Charakteryzuje się on tym, że dowodzi niemożliwości poznania niezależnej od podmiotu przedmiotowości, „,rzeczy samej w sobie”. Subiektywizm ten znajduje swe poparcie $\mathrm{w}$ jednostronnym interpretowaniu najnowszych osiągnięć dziewiętnastowiecznej psychologii zmysłów. Zwolennikiem takiej interpretacji I. Kanta był m.in. J. G. Fichte. Wyniki Krytyki czystego rozumu stawiają zatem I. Kanta nad „przepaścią sceptycyzmu”. Nic tu nie pomaga dowodzenie, że mamy przynajmniej względną wiedzę na temat świata zjawiskowego w granicach „możliwego doświadczenia”, skoro i ta względna wiedza nie może funkcjonować bez pojęcia świata przyrody, które ostatecznie jest wytworem rozumu bez jego oparcia na podstawach „przedmiotowej doniosłości", konstatował H. Struve.

${ }^{15}$ S. Garfein-Garski, Krytycyzm..., s. 100.

${ }^{16}$ H. Struve, Immanuel Kant oraz dziejowa doniosłość jego krytycyzmu, Warszawa 1904, s. 20. 
Dla F. Paulsena, którego praca I. Kant i jego nauka ukazała się w języku polskim w 1902 r., poglądy I. Kanta dotyczące rozpatrywanego problemu należy umieścić w szerszym kontekście teoretycznym. Trzeba rozróżnić trzy momenty: po pierwsze - subiektywną treść świadomości, czyli rzeczywiste postrzeżenia i wyobrażenia w świadomości indywidualnej, po drugie - obiektywny świat zjawisk, ogół wszystkich postrzeżeń możliwych dla pewnej wszechobejmującej świadomości albo świadomości w ogóle, po trzecie - rzeczywistość samą w sobie istniejącą, bez względu na jakikolwiek podmiot „odbierający postrzeżenia”. Subiektywna treść świadomości istnieje bezpośrednio tylko dla pojedynczego podmiotu, który postrzega. Związki pomiędzy pierwiastkami tej świadomości są uwarunkowane empirycznie „albo uwarunkowane asocjacyjnie” jako przypadkowe następstwo w czasie. Świat zjawisk jest natomiast taki sam dla wszystkich podmiotów obdarzonych daną organizacją. Związki są określane przez prawa przyrody, czyli przez „ogólnie uznawane prawidła związków między przedmiotami w przestrzeni i czasie".

Trzeci moment to świat myślowy, leżący poza obrębem form zmysłowych postrzeżeń, dający się ująć w postaci myślnej jako pojęcie konieczne. Ludzkiemu poznaniu, zależnemu od zmysłowego postrzegania, jest on niedostępny. Subiektywna część świadomości jest przedmiotem badania psychologicznego, natomiast świat zjawisk jest właściwym przedmiotem nauki, „W szczególności nauk przyrodniczych”. Przedmiotem absolutnego poznania mógłby być świat myślny, jednakże w poznaniu ludzkim występuje tylko jako „konieczne pojęcie kontrolujące przy krytycznym określaniu naszego poznania”. Gdy natomiast staje się przedmiotem spekulacji, to powstają „pseudonauki starej metafizyki”. Fr. Paulsen pisał: „rozróżnienie subiektywnej treści świadomości i obiektywnego świata zjawisk konieczne jest i ważne. I bez wątpienia tak jest, że świat cały na następstwo stanów świadomości zapatruje się jako na przypadkowe i uwarunkowane, a na następstwo zjawisk w przyrodzie jako na warunkujące i podległe prawom. Nauki przyrodnicze jedynie ten obiektywny związek zjawisk odkryć usiłują. Z drugiej wszakże strony, o ile i tu uwagę krytyczną zrobić wypada, nie rozstrzyga to jeszcze kwestii czy ostatecznie nie należałoby obiektywnego następstwa zjawisk wyprowadzić z następstwa postrzeżeń w świadomości. Prawa mechaniki wyrażają obiektywne następstwo zjawisk, ale następstwo przestrzeni w świadomości stanowi założenie tamtego następstwa: widzimy albo przekonani jesteśmy, że zawsze wiedzieć moglibyśmy, że przy spotkaniu się dwóch kul elastycznych, w ruchu ich następuje określona zmiana, odpowiednia do ich 
masy, prędkości i kierunku ruchu"17. Prawa są formułowane przez umysł, ale nie przez logiczne wnioskowanie, lecz na podstawie zaobserwowanego następstwa w czasie. Żaden umysł nie może przewidzieć reakcji, zanim nie otrzyma określonego spostrzeżenia. Dopiero obserwacja porządku, w jakim następują po sobie dane postrzeżenia, dostarcza umysłowi materiału do formułowania zasad, które określa mianem praw natury. Dostrzec tu można zbieżność z rozumowaniem Hume’a dotyczącym prawa przyczynowości. $\mathrm{Na}$ podstawie obserwacji przebiegu danych postrzeżeń, przebiegających w tych samych okolicznościach, dostrzegamy, że po danych zjawiskach następowały te same zjawiska. W ten sposób umysłowość może tworzyć prawa, których warunkiem musi być zrozumienie danych zjawisk i ich zawiązku w czasie. Co prawda nie byłyby to wtedy prawa bezwarunkowe konieczne i powszechne, „tylko jak wszystkie prawa natury warunkowo prawdziwe”.

Treści powyżej zaprezentowane uwypuklają empiryczną stronę filozofii I. Kanta, empiryczną stronę doświadczenia, jednakże dla wielu autorów tamtego okresu ważne stawało się godzenie empirystów i apriorystów z równoczesnym uwypuklaniem pojęcia siły - jako niezbędnego do wzbogacenia naukowego opisu - o wyjaśnienia nie posiadające implikacji ontologicznych. Wyrazicielem takich poglądów był m.in. M. Wartenberg, który uważał, że w pojęciu prawa tkwią cechy, których nie można poznać w wyniku doświadczenia, nie można też ich empirycznie uzasadnić; są to konieczność i powszechna ważność praw. W procesie poznania przyrody dadzą się tylko wyprowadzić prawidła empiryczne, które są pewnymi uogólnieniami faktów doświadczalnych uzyskanych drogą „indukcji generalizującej”. Nigdy one nie są jednak prawami koniecznie i powszechnie ważnymi, którym „wszystkie zjawiska przyrody bez wyjątku podlegać muszą". W odniesieniu do człowieka dadzą się empirycznie wyprowadzić tylko pewne „maksymy” traktowane jako zasady mające znaczenie dla poszczególnych jednostek funkcjonujących w określonych warunkach. Prawa konieczne i powszechne mogą wynikać jedynie $\mathrm{z}$ apriorycznych praw rozumu. W teorii poznania I. Kanta formalny czynnik poznania, który stanowią czyste formy wyobrażenia i myślenia, tkwi a priori $\mathrm{w}$ samym rozumie, podczas gdy czynnik materialny dostarczający naszemu poznaniu przedmiotów treści polega na doświadczeniu. Prawa, które rozum teoretyczny przypisuje a priori przyrodzie, zawierają w sobie tylko ogólną formę prawidłowości, którą dopiero doświadczenie musi wypełnić konkretną treścią. I. Kant wykazał w Krytyce czystego rozumu istnie-

${ }^{17}$ F. Paulsen, I. Kant i jego nauka, Warszawa 1902, s. 186. 
nie apriorycznego, płynącego z czystego rozumu, niezależnego od doświadczenia poznania przedmiotów, które ogranicza się do świata zjawiskowego stanowiącego przedmiot doświadczenia. W Krytyce czystego rozumu zajmuje zatem I. Kant stanowisko aprioryzmu i racjonalizmu, gdyż rozum teoretyczny w jego filozofii - zdaniem M. Wartenberga - przypisuje a priori prawa przyrodzie, jest twórcą prawidłowości panującej powszechnie w zjawiskach przyrody ${ }^{18}$. Rozum jest tym samym autonomicznym, samorzutnym i niezależnym od empirycznych warunków podmiotem poznania. Przyroda natomiast traktowana jako istnienie rzeczy podlegające prawom powszechnym jest dziełem autonomii rozumu teoretycznego.

W Polsce tamtego okresu rozpowszechniona była także metodologiczna interpretacja twórczości I. Kanta, odrzucająca psychologiczną wykładnię aprioryzmu. Dostrzec można w niej wyraźne wpływy Cohena oraz innych przedstawicieli szkoły marburskiej. Widzimy to chociażby $\mathrm{w}$ twórczości W. M. Kozłowskiego. Uznał on doniosłość kantowskiej teorii poznania, w której odróżnienie formy od treści doprowadziło do rozstrzygnięcia sporu pomiędzy empiryzmem a racjonalizmem. Forma jest aprioryczna i stanowi naszą własność niezależną od doświadczenia, ale niezbędną do jego urzeczywistnienia. Powinna ona poprzedzać każde doświadczenie, którego rzeczywista treść jest przekazywana zmysłowo. Forma i treść tworzą pojęcie. Już Berkeley wytknął - jego zdaniem - bezzasadność nadawania większej przedmiotowości własnościom „pierwszorzędnym wobec drugorzędnych”. Oczywiste jest, że jedne i drugie są $\mathrm{w}$ równej mierze przedmiotowo-podmiotowe. Przewagę podmiotową mają raczej treści wrażeń zmysłowych, które przedstawiają się jako stałe odpowiedniki ,jakiejś nieznanej rzeczywistości”. Natomiast „własności przestrzenne ciała” występują w nauce I. Kanta jako czysto podmiotowe i aprioryczne. Pierwsze są wynikiem współdziałania „rzeczy w sobie" i umysłu, drugie - czystym dodatkiem umysłu. Pojęcie doświadczenia zostaje $\mathrm{w}$ ten sposób zmienione i rozszerzone. Nie ma doświadczenia „czystego”, w każdym pojęciu mamy do czynienia z podwójnym udziałem umysłu, którego treść, chociaż jest podmiotowa, to pochodzi z doświadczenia - jest reakcją umysłu na bodziec zewnętrzny. Forma natomiast jest aprioryczna, jest tym, czym umysł przetwarza wrażenia, „modulując je według wewnętrznych praw swoich".

${ }^{18}$ Por. M. Wartenberg, O kantowskiej krytyce praktycznego rozumu i jej stosunku do krytyki czystego rozumu, Lwów 1911, s. 4-8. Zob. S. Borzym, Wartenberg jako krytyk Kanta, [w:] Dziedzictwo..., s. 189. 
Nie cała wiedza, zdaniem W. M. Kozłowskiego, pochodzi zatem z doświadczenia zmysłowego. W każdym pojęciu jest coś dodanego przez umysł, pewien składnik aprioryczny, który nie może być traktowany jako zakłócający przedmiotowość i doniosłość doświadczenia. Wiązanie pojęć w sądy odbywa się przecież także według apriorycznych „form pojęciowych, czyli kategorii”. Jest to proces podobny do opisanego modulowania wrażeń i tworzenia ich formy - pojęcia. Do takich apriorycznych form pojęciowych należą „zakwestionowane przez filozofię angielską substancja i przyczynowośc”. Jest to proces dodawania do treści formy, w czasie którego tworzy się definicja pojęcia, co nie oznacza wcale dowolności, gdyż bez tych dodanych do pojęć form pojęciowych nie byłoby wcale doświadczenia jako uporządkowanej całości, lecz tylko chaos pojęć. Taki był, zdaniem W. M. Kozłowskiego, pozytywny wynik Krytyki czystego rozumu. Opierała się ona na "niewzruszonej podwalinie wiedzy, zawieszonej w powietrzu przez wątpliwości Hume’a”, była wsparciem dla wiedzy „pozytywnej” i dla metody doświadczalnej. Była bezwzględną negacją dawnej metafizyki racjonalistycznej, dokonującej błędnej interpretacji wszechświata, duszy jako substancji i Boga ${ }^{19}$.

Inaczej problem doniosłości filozofii I. Kanta postrzegał H. Struve. Jego zdaniem I. Kant wykazał jasno różne źródła poznania, określił aprioryczne czynniki zmysłowego poglądu na świat - tym samym określił aprioryczne składniki rozsądku i rozumu, jednakże stosunku tych czynników do świata przedmiotowego ostatecznie nie rozwiązał. Przestrzeń i czas, kategorie i idee są formami naszej umysłowej działalności, czemu się nie da zaprzeczyć, choćby się nawet okazało, że „potrzeba dopełnienia lub zmiany jego szczegółowego poglądu" na te czynniki poznania. Umysł, działając, posiłkuje się bezpośrednio pewnymi formami i prawami jemu właściwymi. Form i praw tych nie można przyjmować z zewnątrz za pomocą doświadczenia, ponieważ samo przyjmowanie jakiejkolwiek treści, a więc i samo doświadczenie, wypływa już z owych form oraz praw umysłu i dokonuje się według nich. Z tego faktu - pisał H. Struve - wyprowadził I. Kant wniosek będący podstawą „jego dualizmu poznawczego, że skoro owe formy są aprioryczne - właściwe samemu umysłowi, to nie mają charakteru przedmiotowego i nie mogą nam dać pojęcia o istocie rzeczy, w ogóle o tym, czym sami umysłowo nie jesteśmy”. Taki wniosek jednakże nie jest wcale uprawniony, bo „współczynniki naszej organizacji umysłowej” mogą stanowić także treść niezależnego od nas

${ }^{19}$ Por. W. M. Kozłowski, Historia filozoficzna powstania i rozwoju idei podstawowych umysłowości wspótczesnej, Warszawa 1910, s. 73-75. 
przedmiotowego bytu, jeżeli je tylko należycie określimy. Wtedy nie będzie tego antagonizmu między podmiotem i przedmiotem, który I. Kant bierze za punkt wyjścia dla swoich rozważań. Najważniejszym zadaniem przyszłości zdaniem H. Struvego - wypływającym bezpośrednio z krytycyzmu I. Kanta jest przezwyciężenie jego dualizmu poznawczego. Jak na pierwszych etapach współczesnej filozofii „postęp polegał na przezwyciężeniu metafizycznego dualizmu Kartezjusza", tak obecnie wyrównanie przeciwstawności między podmiotem i przedmiotem poznania zbliżyć nas może do najważniejszych zagadnień wiedzy ${ }^{20}$.

S. Garfein-Garski w przeciwieństwie do H. Struvego uzasadniał doniosłość krytycyzmu traktowanego jako synteza racjonalizmu i empiryzmu. Sedno tej syntezy leży w odpowiedzi na pytanie: w jaki sposób możliwe są sądy syntetyczne a priori? Dla I. Kanta sąd jest funkcją jedności między naszymi wyobrażeniami, jest jednością wyobrażeń określających obiekt, bez względu na to, czy jest to obiekt dany w doświadczeniu, czy obiekt pomyślany. Sądem analitycznym nazywamy sąd, w którym orzeczenie jest już zawarte w pojęciu podmiotu tak, że zostaje ono wykazane przez „sam rozbiór” tego podmiotu; sądem syntetycznym zaś sąd, w którym orzeczenie zawiera jakieś nowe określenie podmiotu, rozszerza nasze wiadomości o podmiocie i wzbogaca poznanie ${ }^{21}$.

Kwestia sądów analitycznych i syntetycznych jest sporna. Szczególnie można to dostrzec w wypowiedziach logików. Przykładowo krytycyzm w ujęciu Ajdukiewicza miał na celu wyeliminowanie całkowitej przypadkowości i arbitralności sądów przyjmowanych na zasadzie dogmatycznej, posługiwał się zasadą oczywistości, uznając, że jest ona zadowalająca do wstępnego uprawomocnienia sądów, co nie jest równoznaczne $\mathrm{z}$ ich udowodnieniem jako prawdziwych. Natomiast niektórzy inni logicy twierdzili, że sądy syntetyczne wcale nie istnieją, że w pojęciu danego podmiotu zawarte jest już orzeczenie, nawet jeżeli jest ono mu nieznane i faktycznie rozszerza jego wiedzę. Zarzut ten odpierał już S. Garfein-Garski, uwzględniając szczególnie punkt widzenia

${ }^{20}$ Por. H. Struve, Immanuel Kant..., s. 37. Poglądy Kanta na temat idealnego realizmu sprawdzał w tym okresie także A. Skórski. Por. jego recenzję pracy Garfeina-Garskiego pt.: Krytycyzm, „Gazeta Wieczorna”, 1912, nr 622, s. 3.

${ }^{21}$ Por. I. Kant, Krytyka..., s. 70. I. Kant pisał: „[...] we wszystkich sądach, w których pomyślany jest stosunek podmiotu do orzeczenia [...] stosunek ten jest możliwy w sposób dwojaki. Albo orzeczenie B należy do podmiotu A jako coś, co jest (w sposób ukryty) zawarte w pojęciu A, albo B leży całkiem poza pojęciem A, choć pozostaje z nim w związku. W pierwszym wypadku nazywam sąd analitycznym, w drugim zaś syntetycznym". 
teorii poznania. W różnicy między tymi sądami - pisał - nie chodzi o stosunek do subiektu wydającego sądy, lecz o stosunek do obiektu, o obiektywne uzasadnienie sądu, o to mianowicie, że zasadą "połączenia pojęć w sądzie syntetycznym jest doświadczenie przedmiotowe". Sądy analityczne obejmują poznanie pojęć, a sądy syntetyczne poznanie faktów. Sądy syntetyczne możliwe są tylko przez ogląd. Tam zatem, gdzie nie ma bezpośredniej lub pośredniej możliwości oglądu, nie ma sądu syntetycznego ${ }^{22}$.

Według S. Garfeina-Garskiego poznanie dla I. Kanta jest możliwe tylko przez sądy syntetyczne, czyli przez sądy pozostające w pewnym stosunku do oglądu. Gdy nie ma takiego stosunku, to poznanie nie jest możliwe. Uważał on, że zależność taką można dostrzec w „czystym przyrodoznawstwie” i w naukach matematycznych, natomiast w sądach syntetycznych "dotychczasowej metafizyki”, w całej jej transcendencji nie dostrzegamy żadnego stosunku do oglądu. Jej sądy są tylko „pozornie syntetyczne”, nie mają określonego przedmiotu oglądu. Dostrzegamy tu pewne ograniczenie poznania do immanencji, do fenomenów, czyli do zakresu doświadczenia. Dodatek zaś, pisał S. Garfein-Garski, „a priori w owym pytaniu pochodzi stąd, że Kantowi idzie nie tylko o poznanie, ale idzie mu o poznanie prawdziwe, to jest konieczne i powszechnie ważne, a takie gwarantują tylko sądy aprioryczne, nie aposteryczne, czyli czysto doświadczalne"23.

Innego zdania był A. Żółtowski stwierdzając, że „Kant przeocza oczywiście, iż sąd o tym, czy znajdujemy się w sferze zmysłowej, czy nadzmysłowej, wcale nie jest rzeczą tak prostą, jakby się zdawać mogło. Umysł przecież mający sądzić o zmysłowości, już ponad sferą się znajduje i rozporządzać musi elementami nie przystającymi bezpośrednio do przedmiotów zewnętrznych doświadczenia" ${ }^{24}$.

Wydaje się jednak, że dla I. Kanta sąd jest tylko pewnym pośrednim poznaniem przedmiotu, a więc przedstawieniem przedmiotu. Intelekt posiada zdolność wydawania sadów, zdolność do myślenia. Myślenie zaś to poznanie przez pojęcia. Funkcja myślenia w sądzie da się zobrazować czterema rozróżnieniami. Są to sądy co do ilości, jakości, stosunku i co do modalności. Sądom tym odpowiada tablica transcendentalna pojęć rozsądkowych. Są to czyste pojęcia intelektu, odnoszące się a priori do przedmiotów naoczności

\footnotetext{
${ }^{22}$ Por. tamże, s. 136 i 307.

${ }^{23}$ S. Garfein-Garski, Krytycyzm..., s. 108.

${ }^{24}$ A. Żółtowski, Filozofia Kanta, jej dogmaty, złudzenia i zdobycze, Poznań 1923, s. 203.
} 
w ogóle, dzięki którym dane naoczne uchodzą za określone pod względem jednej z logicznych funkcji sądzenia.

W sądzie analitycznym widzi I. Kant konieczność rozstrzygania o nim. Jeżeli ma on być twierdzący, to dołączamy do niego tylko to, co w nim już było pomyślane, jeżeli ma być przeczący, to tylko wykluczamy z niego przeciwieństwo jego samego, w sądach syntetycznych mamy natomiast wyjść poza dane pojęcie, żeby coś całkiem innego niż to co było w nim pomyślane, rozważyć w pewnym do niego stosunku. Stosunek ten nie jest jednak stosunkiem tożsamości ani sprzeczności, a dodatkowo nie mamy możliwości po samym sądzie poznać jego prawdziwości ani fałszywości. Dla I. Kanta poznanie ma mieć przedmiotową realność, odnosić się do pewnego przedmiotu i mieć w nim swoje znaczenie. By tak było, przedmiot musi być w jakiś sposób dany, gdyż inaczej wszelkie pojęcia są puste: „Wprawdzie coś się przez nie myśli, ale faktycznie niczego się nie poznaje przez to myślenie, lecz jedynie bawi się przedstawieniami”. W poznaniu musimy zatem odnosić nasze przedstawienia tego przedmiotu do doświadczenia. Możliwość doświadczenia jest tym, co nadaje całemu naszemu poznaniu a priori przedmiotową ważność. Polega ono na syntetycznej jedności zjawisk, na dokonującej się według pojęć syntezie przedmiotu zjawisk w ogóle, bez której nie byłoby poznaniem. Doświadczenie ma więc u swego podłoża zasady formy a priori, a mianowicie „ogólne prawidła jedności utrzymującej się w syntezie zjawisk, przedmiotowa realność tych prawideł, jako warunków koniecznych, da się zawsze wykazać w doświadczeniu, a nawet w jego możliwości”25.

Inaczej kantowskie poznanie postrzegał Adam Mahrburg, stwierdzając, że „poznajemy świat nie takim, jakim on jest niezależnie od naszego umysłu, lecz budujemy wiedzę o świecie z materiału doświadczalnego tak, jak na to pozwala swoista organizacja naszego umysłu. Ten swój pomysł Kant nazywa odkryciem kopernikańskim w filozofii i w nim upatruje główny swój czyn bohaterski”26. Istotę kantyzmu upatrywał A. Mahrburg w połączeniu racjonalizmu z empiryzmem. Traktował poznanie jako jedność treści i formy, tym samym jako podmiotowość i przedmiotowość zarazem. Odżegnywał się od pojęcia czystego doświadczenia uwarunkowanego jedynie przez energię zmysłów. Rzeczywistość doświadczalna była dla niego tylko produktem właściwych podmiotowi form poznania a priori.

${ }^{25}$ Por. I. Kant, Krytyka..., s. 307-309.

${ }^{26}$ A. Mahrburg, Emanuel Kant, [w:] Pisma filozoficzne, t. 2, s. 291. 
Taka empiryczno-racjonalistyczna koncepcja kantyzmu pomijała założenia światopoglądowe, które zostały określone nie w Krytyce czystego rozumu, lecz w pozostałych dwóch krytykach. W nich twórczość podmiotu nie zostaje ograniczona do procesu poznania, który sprowadza się do włączenia materii w doświadczenie, lecz jest także inspiratorką „moralności i piękna”.

Istniejąca przepaść pomiędzy wymienionymi krytykami, pomiędzy racjonalizmem a woluntaryzmem, inspirowała twórczość następców I. Kanta. Wykorzystali oni sformułowane przez niego pojęcie „świadomości w ogóle”. W tę konstrukcję czystego „ja” J. G. Fichte wlewa prometeuszowską iskrę woli. Powstaje w ten sposób „ja” aktywne, tworzące całą rzeczywistość subiektywno-obiektywną. Koncepcja „niebosiężnego ducha”, która inspirowała filozofię i poezję romantyczną lekceważącą doświadczenie, dalece odbiegała od kantowskiego krytycyzmu.

J. G. Fichte faktycznie przyjął za całą rzeczywistość Absolut, Ideę, Myśl będącą wspólnym źródłem podmiotu i przedmiotu. Jest on dany w formie świadomości każdej jednostki ludzkiej, natomiast świat istniejący to tylko przedstawienie, które jest treścią ludzkiej jaźni. Trzeba pamiętać także, że J. G. Fichte uznawał człowieka za istotę wolną, nie podlegającą ani przyrodzie, ani transcendencji partycypującej w życiu społecznym. Twierdził, że na podstawie więzi społecznych wyrasta prawo moralne manifestujące się w kulturze, która może pokonać partykularyzm i egoizm jednostek, ponieważ w kulturze właśnie urzeczywistniają się ogólnoludzkie zadania, powołanie człowieka.

Aktywność „Ja" prowadzi do przeciwstawienia się partykularyzmowi interesów jednostkowych oraz umożliwia zdolność tworzenia wartości moralnych. Przedmiot jest dzięki temu uzależniony od działającego podmiotu, co prowadzi do uznania pełnej odpowiedzialności człowieka za własne postępowanie, a tym samym postępowanie ludzkości. Wolność uzyskuje zatem pełne znaczenie nie w spotkaniu człowieka $\mathrm{z}$ rzeczami, lecz w spotkaniu $\mathrm{z}$ innymi podmiotami. Jednostka była dla J. G. Fichtego z jednej strony niepowtarzalnym indywiduum, $\mathrm{z}$ drugiej zaś nosicielem właściwości ogólnoludzkich.

W Polsce na przełomie XIX i XX wieku z różnych kierunków krytycyzmu ceniono „teologiczny krytycyzm” i filozofię wartości Windelbanda stojącą najbliżej myśli transcendentalnego idealizmu. Twierdzono, że próba syntezy krytycyzmu i metafizyki proponowana m.in. przez O. Liebmanna jest zgodna z jego duchem. W Polsce takie stanowisko reprezentowali H. Struve i M. Straszewski. W ich ujęciu metafizyka nie może zapewniać prawdy, czyli poznania koniecznego i powszechnego, ale może dać poznanie prawdopodobne, może dać pewne zaspokojenie potrzeb transcendentalnych. 
W Polskiej tradycji filozoficznej przełomu XIX i XX wieku oceniano filozofię I. Kanta także inaczej. A. Żółtowski pisał:

Sprowadzając widoczny zwrot $\mathrm{w}$ rozwoju ludzkiej myśli, filozof ten nie jest ani trochę nowatorem, rwącym się dalej aniżeli sięga prawdziwy jego dorobek. Przeciwnie, instynktem i świadomymi dążeniami należy do tego świata „oświecenia”, któremu przecież naznacza koniec. Przez swą analizę poznania, przez antynomię rozumu, przez ideę celowości daje początek gruntownemu odnowieniu logiki i przygotowuje rozkwit filozoficznej spekulacji, nie przestając szemrać na metafizykę i obiecując sobie zamknąć umiejętność poznania raz na zawsze w granicach możliwego doświadczenia [...]. Nauka jego - niezdecydowana, niezgodna z sobą, pełna domysłów, lecz pełna też uprzedzeń, liczyć się musi do szeregu takich fermentów zarazem rozkładających i twórczych, które nie przestają trawić ludzkiego ducha, nie dając mu spocząć ani odbudować się na nowej podstawie ${ }^{27}$.

J. N. Szuman uznał zaś I. Kanta za filozofa kompromisowego, ponieważ nie odrzuca on prawie nic z dorobku „zwalczających się wzajemnie szkół filozoficznych", a stara się

na swój sposób jedno z drugim pogodzić. Zasada taka musi oczywiście poświęcać na ołtarzu pewnej wszechstronności jednolitość przewodniej myśli filozoficznej [...]. Umie on pogodzić z sobą doświadczenie i pojęcia a priori jako źródła poznania, świat wyobrażeń i przedmiotowy, realność oglądu, zjawisko i rzecz jako taką w jednym i tym samym przedmiocie, wolność woli i konieczność rządzącą bytem; nie waha się wreszcie przeciwstawiać nieśmiertelnej duszy człowieka idei osobowego Boga i przytaczać dowodów Jego istnienia jako ostatecznego źródła przypadkowych szeregów zjawiskowych i oparcia dla miotanego wątpliwościami umysłu ${ }^{28}$.

J. N. Szuman uważał, że kompromisowość I. Kanta jest zbytecznym i szkodliwym dodatkiem do filozofii krytycznej. E. Krzymuski natomiast, podobnie jak S. Garfein-Garski, uznawał, że:

jeśli o którym filozofie można powiedzieć, iż myślą nie tylko objął cały widnokrąg życia dostępny dla rozumu ludzkiego pod jakimkolwiek względem, lecz nadto wszystko, co o tym widnokręgu może być wiadome z pewnością nie-

${ }^{27}$ A. Żółtowski, Filozofia..., cyt. wyd., s. 499.

${ }^{28}$ J. N. Szuman, Pogląd krytyczny na metafizykę Kanta, Poznań 1902, s. 179. 
wzruszoną, związał w jedną całość i poddał rozbiorowi wedle jednych i tych samych zasad krytyki naukowej, to niezawodnie sąd ten należy nam wydać o Kancie, o którym słusznie powiedziano, że był największym metafizykiem czasów nowożytnych i że co do geniuszu filozoficznego dorównywał mu tylko Arystoteles ${ }^{29}$.

W polskiej tradycji filozoficznej kantyzm był postrzegany przez lupę jego idealistycznej interpretacji. Taki krytycyzm rozpowszechniał modernizm oraz inne szkoły filozoficzne. Dostrzegano w filozofii I. Kanta tylko zjawisko, sporadycznie zastanawiano się natomiast nad jego racjonalistycznym „przejawianiem się". Jednocześnie sprzeciwiano się tej tradycji, uznając możliwość apriorycznego poznania obu światów przez tkwiące $\mathrm{w}$ podmiocie poznającym formalne zasady poznania. Uważano, że w teorii I. Kanta należy rozróżnić subiektywną treść świadomości, czyli rzeczywiste postrzeżenia i wyobrażenia w świadomości indywidualnej od rzeczywistego świata zjawisk, czyli ogółu wszystkich możliwych dla pewnej świadomości postrzeżeń oraz od rzeczywistości istniejącej jako „sama w sobie”, bez względu na jakikolwiek podmiot poznający ${ }^{30}$.

Część polskich filozofów tego okresu krytycznie odnosiła się do interpretacji kantyzmu określanej mianem psychologicznej. Sceptycznie oceniali interpretację zaproponowaną przez Langego i Helmholtza, podkreślającą fenomenalizm i subiektywizm I. Kanta. W tym ujęciu umysł podmiotu poznającego stawał się wszystko konstruującym po swojemu narzędziem poznania. Myśl natomiast była równie subiektywna jak wrażenia. Niektórzy myśliciele w tym S. Garfein-Garski dostrzegali, że punktem wyjścia kantyzmu może być ontologia, gdyż prawomocności nauki trzeba szukać w całościowej strukturze świata empiryczno-racjonalistycznego. Psychologia w ogóle dawała taką możliwość, ponieważ refleksja nad poznaniem mogła być jednocześnie refleksją nad sposobem bycia i podstawowymi formami przedmiotowości. Krytyka zatem stawiałaby pytania o warunki naszego poznania w kontekście warunków funkcjonowania świata podmiotowo-przedmiotowego. Twórcy psychologicznej interpretacji kantyzmu możliwości tej jednak - zdaniem S. Garfeina-Garskiego - nie wykorzystali i popadli w „starą metafizykę”.

\footnotetext{
${ }^{29}$ E. Krzymuski, Teoryja karna Kanta ze stanowiska jego ogólnej nauki o rozumie praktycznym, Kraków 1882, s. 2.

${ }^{30}$ Zbliżone poglądy zostały zaprezentowane w pracy Fr. Paulsena: I. Kant..., s. 444, która niewątpliwie była znana autorowi.
} 
Zasadniczo polscy interpretatorzy filozofii I. Kanta domagali się uzgadniania wyników badań teoriopoznawczych $\mathrm{z}$ osiągnięciami nauk przyrodniczych. Pogląd ten korespondował $\mathrm{z}$ antymetafizycznym programem pozytywistów polskich, a szczególnie z jego nową formułą, zwaną „,nowokrytycyzmem". To skłaniało do przeformułowania kantowskiej teorii poznania w duchu ewolucjonizmu oraz uwzględniania osiągnięć psychologii, nie upoważniało jednak do subiektywistyczno-psychologicznej interpretacji kantyzmu oraz bezwzględnej jedności filozofii I. Kanta z naukami przyrodniczymi.

Wyjątkowo traktowano kantyzm jako swoistą syntezę racjonalizmu $\mathrm{z}$ empiryzmem, świata fenomenów i noumenów. Postrzegano jako syntezę, której sedno leży w odpowiedzi na pytanie, w jaki sposób możliwe są sądy syntetyczne a priori. Sądy te zaś są funkcją jedności między wyobrażeniami podmiotu określającymi obiekt dany w doświadczeniu i pomyślany. Znaczna część polskich interpretatorów kantyzmu odwoływała się do niemieckiej refleksji filozoficznej ${ }^{31}$, która była często obciążona idealistyczną wizją kantyzmu. Wizją dominującą także w polskiej świadomości filozoficznej.

\section{Bibliografia}

Bochenek K., Gawor L., Jedynak A., Kojkoł J., Filozofia polska okresu międzywojennego. Zarys problematyki, Gdynia 2013.

Bochenek K., Gawor L., Michalik-Jeżowska M., Wójtowicz R., Zarys historii filozofii polskiej, Rzeszów 2013.

Borzym S., Filozofia polska 1900-1950, Wrocław-Warszawa-Kraków 1991.

Borzym S., Poszukiwania nowej epistemologii, [w:] Zarys dziejów filozofii polskiej 1815-1918, red. A. Walicki, Warszawa 1983.

Dobrzycki W., Historia stosunków międzynarodowych w czasach nowożytnych (1815-

1990/91), [w:] Stosunki międzynarodowe - geneza, struktura, dynamika, red. E. Haliżak, R. Kuźniar.

Filozofia Kanta i jej recepcja, red. D. Bęben, A. J. Noras, Katowice 2011.

Filozofia Kanta i jej recepcja, red. nauk. R. Kozłowski, Poznań 2000.

Galos A., Czapliński Cz., Historia Niemiec 1789-1871, Warszawa 1980.

Garfein-Garski S., Krytycyzm, [w:] W poszukiwaniu prawdy, Kraków 1911.

Garfein-Garski S., Krytycyzm, „Gazeta Wieczorna”, 1912.

Garfein-Garski S., Psychada, „Ateneum”, 1892.

${ }^{31}$ Por. H. Schnädelbach, Filozofia w Niemczech 1831-1933, PWN, Warszawa 1992, s. 423. 
Gawor L., Myśliciele mało znani. Filozofia polska końca XIX wieku i pierwszej dekady XX wieku, Rzeszów 2001.

Hochfeldowa A., Orientacja nowokrytyczna, [w:] Filozofia i myśl społeczna w latach 1865-1895, Warszawa 1980.

Jerusalem W., Wstęp do filozofii, Warszawa 1926.

Kant I., Krytyka czystego rozumu, Warszawa 1957.

Kołakowski L., Immanuel Kant, [w:] O co nas pytają wielcy filozofowie, Kraków 2006.

Kozłowski W. M., Historia filozoficzna powstania i rozwoju idei podstawowych umysłowości współczesnej, Warszawa 1910.

Krzymuski E., Teoryja karna Kanta ze stanowiska jego ogólnej nauki o rozumie praktycznym, Kraków 1882.

Kukiel M., Dzieje polityczne Europy od rewolucji francuskiej, Londyn 1992.

Kupś T., Filozofia religii Immanuela Kanta, Toruń 2008.

Osiągnięcia polskiej psychologii w okresie międzywojennym, red. K. Czarnecki, Katowice 1981.

Paulsen Fr., I. Kant i jego nauka, Warszawa 1902.

Raciborski A., Ogólny zarys systemu filozofii, t. 1, Lwów 1892.

Schnädelbach H., Filozofia w Niemczech 1831-1933, PWN, Warszawa 1992.

Schultze F., Spirytyzm, czyli o obcowaniu z duchami, Warszawa 1884.

Siemek M. J., Transcendentalizm jako stanowisko epistemologiczne, [w:] Dziedzictwo Kanta, Warszawa 1976.

Skoczyński J., Woleński J., Historia filozofii polskiej, Kraków 2010.

Struve H., Immanuel Kant oraz dziejowa doniosłość jego krytycyzmu, Warszawa 1904.

Struve H., Wstęp krytyczny do filozofii, czyli rozbiór zasadniczych pojęć o filozofii, Warszawa 1903.

Symotiuk S., Pojmowanie krytycyzmu i model krytyki w polskich pracach filozoficznych, Lublin 1987.

Szuman J. N., Pogląd krytyczny na metafizykę Kanta, Poznań 1902.

Tarle E., Dzieje Europy (1871-1919), Warszawa 1961.

Tatarkiewicz W., Historia filozofii, t. 3, Warszawa 1990.

Tatarkiewicz W., W dwieście pięćdziesiąta rocznicę urodzin Kanta, [w:] Dziedzictwo Kanta, Warszawa 1976.

Wartenberg M., O kantowskiej krytyce praktycznego rozumu i jej stosunku do krytyki czystego rozumu, Lwów 1911.

Zarys dziejów filozofii polskiej 1815-1918, red. nauk A. Walicki, Warszawa 1983.

Żelazny M., Idea wolności w filozofii Kanta, Toruń 2001.

Żółtowski A., Filozofia Kanta, jej dogmaty, złudzenia i zdobycze, Poznań 1923. 


\section{Abstract \\ Immanuel Kant in Poland. Selected Problems of Reception at the Turn of the 19th and 20th Centuries}

The article interprets the reception of Immanuel Kant's philosophy in Poland at the turn of the $19^{\text {th }}$ and $20^{\text {th }}$ century. The author points out that Kantianism, in the Polish philosophical tradition, has been viewed through the prism of its idealistic interpretations. Such a criticism has spread modernism and various other philosophical currents. A part of Polish philosophers of that time were critical in the treatment of the so-called psychological interpretation of Kantianism. They skeptically evaluated the interpretation proposed by Lange and Helmholtz, which underlined Kant's phenomenalism and subjectivity.

The author claims that Polish interprets of Immanuel Kant's philosophy essentially demanded that results of theory-cognitive research and achievements in the fields of natural sciences should agree with each other. This idea corresponded to the antimetaphysical programme of Polish positivists, especially with its new formula calles "neo-criticism". Kantianism was treated as a peculiar synthesis of rationalism and empiricism, a universe of phenomena and noumena.

Key words: Polish philosophy, Immanuel Kant, reception 